\title{
Bazı Hibrit Mısır (Zea mays L.) Çeşitlerinin Muş Ekolojik Şartlarında Performanslarının Belirlenmesi
}

\author{
Sami AKAN ${ }^{1}$, Hasan KILIÇ $\mathscr{8}$ \\ ${ }^{1}$ Tarım ve Orman İl Müdürlüğü Muş, TÜRKIYYE \\ ${ }^{2}$ Tarla Bitkileri Bölümü, Ziraat Fakültesi, Bingöl Üniversitesi, Bingöl, TÜRKIYYE. \\ $\bowtie$ : hkilic@ bingol.edu.tr, (D) 1 000-0002-8635-4453, (D)20000-0002-5242-9680
}

Geliş (Received): 25.02.2021Ｄüzeltme (Revision):29.04.2021～Kabul (Accepted): 22.05.2021

\begin{abstract}
ÖZET
$\mathrm{Bu}$ araştırma, Muş ekolojik şartlarına uygun dane mısır çeşitlerini belirlemek amacıyla 2015 yılı ana ürün üretim sezonunda yürütülmüştür. Tesadüf blokları deneme desenine göre üç tekerrürlü olarak kurulan bu denemede, onbeş tek melez mısır çeşidi kullanılmıştır. Denemede kullanılan çeşitler arasında tane verimi bakımından önemli farklılıklar belirlenmiş olup en yüksek dane verimi $1193.9 \mathrm{~kg} \mathrm{da}^{-1}$ ile Dekalp 6724 çeşidinden elde edilirken, en düşük dane verimi de $800.7 \mathrm{~kg} \mathrm{da}^{-1}$ ile Adasa-16 çeşidinden elde edilmiştir. Çalışma sonucunda düşük hasat nemi açısından Dekalp-6101 ve Ada-8924 ön plana çıkarken, dane verimi açısından ise Dekalp 6724, Kalends ve As-71 en ümitvar çeşitler olarak tespit edilmişlerdir.
\end{abstract}

Anahtar Kelimeler: Ana ürün, hasat nemi, mısır, Muş ili, verim ve verim unsurları

\section{The Determination of Performance of Some Hybrid Corn Varieties Under Muş Ecological Conditions}

\section{ABSTRACT}

This study was conducted to determine appropriate maize varieties for grain production in Muş ecological conditions. The research was conducted during main crop growth season of 2015. The experimental design was a randomized complete block with three replication and fifteen corn genotypes were used in the experiment. Results revealed that, considerable differences were found among varieties in grain yield. The highest grain yield was obtained in Dekalp6724 variety with $1193.95 \mathrm{~kg} \mathrm{da}^{-1}$ while the variety with the lowest grain yield was Adasa-16 with $800.70 \mathrm{~kg} \mathrm{da}{ }^{-1}$. As a result of the study, Dekalp-6101 and Ada-8924 stood out in terms of low grain moisture content, while Dekalp 6724, Kalends and As-71 were identified as the most promising varieties in terms of grain yield.

Key words: Grain corn, main crop, moisture content, Muş province, yield and yield components

\section{Gİiș}

Misır, insan ve hayvan beslenmesinde doğrudan kullanıldığı gibi sanayinin birçok dalında da yaygın bir şekilde değerlendirilmektedir. Ülkemizde misır; yem, nişasta, glikoz, yağ ve biyoetanol üretiminde kullanılmakta olup, daha ziyade Çukurova, Amik Ovası, İç Anadolu ve Güneydoğu Anadolu Bölgeleri'nde yetiştirilmektedir [1]. Mısır yetiştiricliği makineli tarıma uygun olupı daha az insan iş gücüne ihtyaç duymaktadır. Ayrica gerek ana ve gerekse ikinci ürün olarak yetiştirilmeye uygun olması, hastalık, zararlı ve yabancı ot idaresininin diğer kültür bitkilerine göre kolay ve ucuz olması ile pazarda alıcı bulması gibi sebeplerden dolayı üreticiler tarafından tercih edilmektedir. Son zamanlarda biyoetanol üretiminde tercih edilmesi misırın önemini daha da artırmıştır. Ülkemizde artan hayvan sayısına paralel yem ihtiyacı da o nispette artmaktadır. Bu sebeple yüksek verim potansiyeline sahip bir $\mathrm{C} 4$ bitkisi olan mısır ülkemiz kesif yem ihtiyacını karşılamada önemli bir ürün olarak yerini muhafaza etmektedir. Mısır hasadı sonrası kalan sap-saman ve sömekler ya yakılarak veya toprağa karıştırılarak değerlendirilmektedir. Bunun yerine sap-samanın kaba ve kesif yem açığını kapatmaya esas haylaj yapım yöntemleri üzerinde durularak ekonomiye kazandırılması daha uygun olacaktır [2]. Mısır, tahıl ürünleri içerisinde ekim alanı bakımından dünya sıralamasında ikinci, üretim ve verimde ise ilk sırada yer almaktadır. Ülkemizde ise 0.59 milyon hektar ekim alanı ve 6.5 milyon ton üretim ile buğday ve arpadan sonra yer almaktadır [3]. Muş ilinde tarıma ayrilan toplam alan 344.842 ha. olup ancak 63 ha. alannda ana ürün misır ekimi yapılabilmektedir. Tane veriminin yaklaşı $710 \mathrm{~kg} \mathrm{da}^{-1}$ alındığı ana ürün mısırda toplam üretim 492 tondur [4]. Muş ilinde küçükbaş hayvan sayısı 1.235.552, büyükbaş hayvan sayısı 31.881 ad. [4] olup, hammaddenin çoğunluğunu il dişından temin eden iki adet yem fabrikası da bölge kesif yem ihtiyacını karşılamaktan uzaktır. Bölgede kurutma tesislerinin olmaması misır üretimini olumsuz etkileyen faktörlerden biri olarak görülmektedir. Ayrancı ve Sade (2004) [5], Konya ekolojik şartlarında dane amaçlı 
olarak yetiştirilebilecek melez mısır çeşitlerini belirlemek amacıyla yürüttükleri bir çalışmada; dane veriminin 644-1091 $\mathrm{kg} \mathrm{da}^{-1}$, bitki boyunun 162.1-214.9 $\mathrm{cm}^{-1}$, ilk koçan yüksekliğinin 72.2-116.3 $\mathrm{cm}^{-1}$, tane/koçan oranının \% 74.8-85.1, tepe püskülü çıkış süresinin ise 62.3-73.3 gün ${ }^{-1}$ arasında değiştiğini rapor etmektedirler. Deneme lokasyonuna en yakın Bingöl 'de ana ürün misır adaptasyonu ile alakalı yürütülen bir çalışmada en yüksek tane verimi $1797.00 \mathrm{~kg} \mathrm{da}^{-1}$ ile Ada-7-20 genotipinden sağlanmıştır (Demiray ve Kılıç (2015) [6]. Tosun (1967) [7], Erzurum şartlarında yedi melez misır çeşidi ile yaptığı bir araştırmada; erken gelişen çeşitlerde yaş ve kuru sap verimlerinin daha az, buna karşılık tane verimlerinin daha fazla olduğunu, geç olgunlaşan çeşitlerde erkenci çeşitlere oranla hasıl veriminin ve bitki boyunun daha fazla olduğunu tespit etmiştir. Araştırıcı, en erkenci M-202 çeşidinden 2 yıllık ortalamaya göre $376 \mathrm{~kg} \mathrm{da}^{-1}$ birim alan tane verimi aldığını bildirmiştir. Tezel ve ark. (2012) [8], Konya ana ürün şartlarında yürüttükleri bir çalışmada incelenen özellikler yönüyle 21 tek melez misır genotiplerinden ADA 9.10, ADA 9.4, ADA 9.7, ADA 6.15 ve ADA 9.8'in bölge şartları için ümitvar olduklarını bildirmişlerdir. Diğer bitki türlerinde olduğu gibi misır üretiminde de azami verimi sağlayan faktörlerin başında ekolojilere adapte olabilen uygun genotiplerin yetiştirilmesi gelmektedir. $\mathrm{Bu}$ açıdan hedef bölgenin agroekolojisine uygun çeşitlerin adaptasyon denemeleri ile belirlenmesi önemli bir unsurdur [9]. Bu çalışma, geçici taban su seviyesi probleminden dolayı kışlık ekilişlerin sorun olduğu yerlerin değerlendirilmesi yanısıra üreticiye farklı ürün alternatifi sunmak üzere yaz devresinde farklı olum gurubuna sahip farklı hibrid dane mısır çeşitlerinin ana ürün olarak adaptasyon kabiliyetleri ile mısır üretiminde verimi sınırlayabilecek faktörlerin belirlenmesi amaciyla yürütülmüştür.

\section{MATERYAL ve YÖNTEM}

$\mathrm{Bu}$ araştırmada, farklı kuruluşlardan temin edilen 15 melez mısır çeşidi kullanılmıştır (Tablo 1).

Deneme 15 mısır çeşidinin performanslarını belirlemek amacıyla, 2015 yılında Muş ili Merkez Çögürrlü köyünde ana ürün sezonunda yürütülmüştür. Muş İli ülkemizin doğusunda " $38^{\circ} 45$ '53.27" kuzey paralelleri ve “41³2'28.67” doğu meridyenleri arasında yer almakta olup, $1351 \mathrm{~m}$ irtifaya sahiptir (Şekil 1). Denemenin yürütüldüğü alan, akarsularca taşınmış alüviyal topraklar olup, etkili toprak derinliği fazla, killi-tınlı bünyeye sahip eğimi düze yakın, birinci sınıf tarım arazisidir. Denemenin yürütüldüğü toprak, organik maddece fakir (\%1.23), tuzluluğu önemsiz (103 mS), kireç oranı (\%4.01) düşük olup, pH'1 7.23 olup nötr bir özellik göstermektedir. Ayrıca, azotça fakir, $\mathrm{K}_{2} \mathrm{O}$ miktarı (20.15 $\left.\mathrm{kg} \mathrm{da}^{-1}\right)$ bakımından zengin, fosforca $\left(\mathrm{P}_{2} \mathrm{O}_{5}\right)$ yeterli (5.04 $\mathrm{kg} \mathrm{da}^{-1}$ ) seviyede bulunmaktadır.
Tablo 1. Denemede Kullanılan Hibrid Mısır Çeşitlerinin Olum Grupları ve Üretici Kuruluşları

\begin{tabular}{lll}
\hline Çeşitler & Üretici Kuruluş & $\begin{array}{l}\text { Olum Gurubu } \\
\text { (FAO) }\end{array}$ \\
\hline Sakarya & Misır Araşt. Enst. Müd. & 650 \\
Agn 720 & Agromar & 700 \\
Ada 8924 & Misır Araşt. Enst. Müd & 450 \\
Ada 523 & Misır Araşt. Enst. Müd & 650 \\
Ada 334 & Misır Araşt. Enst. Müd & 600 \\
Dekalp 6724 & Monsanto & 700 \\
Dekalp 6101 & Monsanto & 600 \\
Dekalp 5783 & Monsanto & 500 \\
Kalends & Türk Tarım T.A.Ş & 700 \\
Kws Kebos & Türk Tarım T.A.Ş & 700 \\
Suerto & Polen Tohumculuk & 700 \\
As 71 & Polen Tohumculuk & 580 \\
Adasa 16 & Doğu Akdeniz TAE & 650 \\
Breaker & Sygenta & 600 \\
Fito Carella & Fito & 700 \\
\hline
\end{tabular}

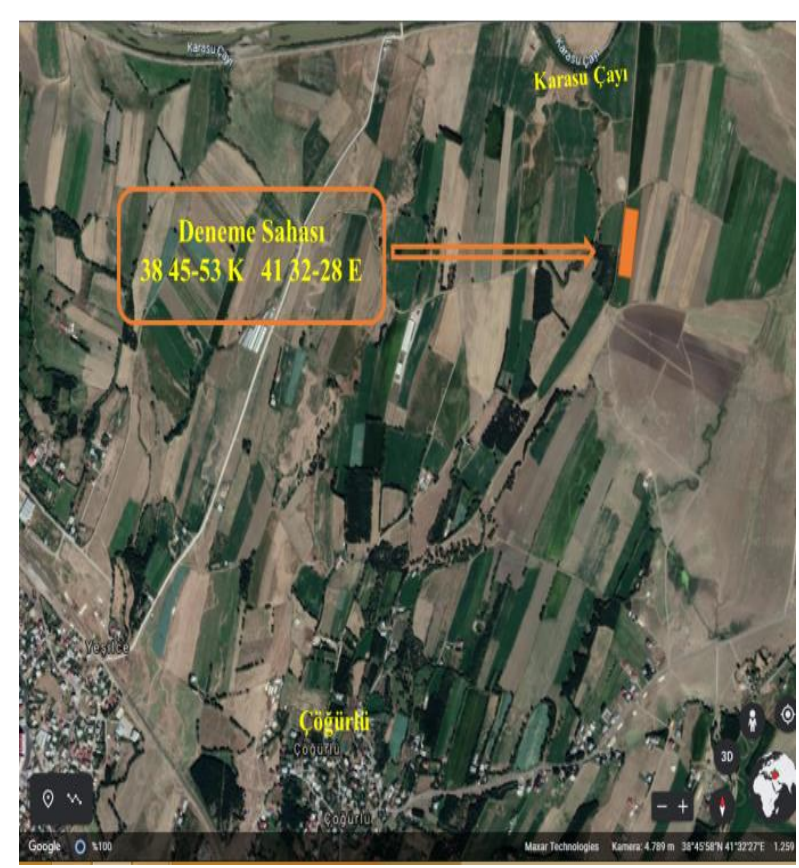

Şekil 1. Denemenin Yürütüldüğü Lokasyon

Doğu Anadolu'nun karasal iklim özelliklerine sahip Muş ilinde yetiştirme süresi boyunca deneme sonucunu etkileyebilecek ekstrem bir iklim değeri gözlenmemekle birlikte uzun yıllar ortalaması ile mukayese edildiğinde daha serin bir sezon olduğu anlaşılmaktadır (Tablo 2).

Tablo 2. Denemenin Yürütüldüğü Uzun Yıllar ve 2015 Yılına Ait Bazı İklim Verileri

\begin{tabular}{lllllll}
\hline Aylar & \multicolumn{2}{c}{ Yağ 1 m $\mathrm{mm}$} & \multicolumn{2}{c}{$\begin{array}{l}\text { Minimum } \\
\text { Sicaklık }{ }^{\circ} \mathrm{C}\end{array}$} & \multicolumn{2}{c}{$\begin{array}{c}\text { Maksimum } \\
\text { Sicaklık }\end{array}$} \\
\hline & \multicolumn{3}{c}{$\mathrm{C}$} \\
Mayıs & 67.6 & 66 & 8.7 & 8.0 & 21.2 & 20.5 \\
Haziran & 27.5 & 25 & 12.6 & 11.4 & 27.4 & 26.2 \\
Temmuz & 6.6 & 6 & 16.9 & 15.2 & 32.9 & 31.5 \\
A ğustos & 3.7 & 6 & 16.8 & 14.8 & 33.1 & 31.7 \\
Eylül & 14.4 & 13 & 12.1 & 10.6 & 28.2 & 27.3 \\
Ekim & 64.1 & 64 & 6.7 & 5.6 & 19.8 & 19.2 \\
\hline
\end{tabular}


Tesadüf blokları deneme desenine göre 3 tekrarlamalı kurulan denemede, parsellerin boyutu $5 \times 2.8=14 \mathrm{~m}^{2}$ olarak alınarak bitkiler 4 sira halinde $70 \times 25 \mathrm{~cm}$ ekim normuyla 1 Haziran 2015 tarihinde ekilmişlerdir. Denemede $20 \mathrm{~kg}$ saf azot ve $15 \mathrm{~kg} / \mathrm{da}$ saf fosfor kullanılmış olup, fosforun tamamı ile azotun yarısı ekimde, geriye kalan azotun yarısı ise 20 Temmuz tarihinde bitkiler $40-50 \mathrm{~cm}$ boyuna ulaştı̆̆ında verilmiştir. Misır bitkisinin gelişme durumu, hava ve toprak şartlarına bağlı olarak karık sulama yöntemiyle, seyreltmeden sonra bitki boyları 10-15 cm olduğunda, üst gübreleme sonrası bitki boyları 40-50 cm olduğunda, tepe püskülü çıkarmanın hemen öncesi, koçan oluşum dönemi ve süt olum dönemlerinde olmak üzere toplamda $5 \mathrm{kez}$ sulanmıştır. Yabancı otlarla mücadele elle çapalama şeklinde yapılmıştır. Çeşitler fizyolojik olgunluklarını tamamladıktan sonra 11 Ekim 2015 tarihinde, her parselin orta kısmındaki iki sırada bulunan bitkiler elle toplanarak hasad edilmiştir. Tepe püskülü çıkış süresi, bitkide koçan sayısı, ilk koçan yüksekliği, bitki boyu, hasat nemi, koçan dane ağırlığı, dane/koçan oranı, bin dane ağırlığı ve dane verimi, gibi özelliklerin ölçümleri Kılıç ve ark. (1999) [10]; Anonim (2005) [11]; Gül ve ark. (2008) [12], Sakin ve ark. (2016) [13]; kullandıkları yöntemler esas alınarak yapılmıştır. Öğütme cihazı kullanılarak toz haline getirilen danelerde protein içerikleri, Dumas yöntemleriyle Dumatherm cihazı kullanılarak belirlenmiştir [14, 15]. Elde edilen gözlem değerleri JMP 7.0 istatistik paket programı kullanılarak varyans analizine tabi tutulmuş olup, ortalamalar arasındaki farklar $(\mathrm{P}<0.05)$ Tukey testi ile mukayese edilmiştir.

\section{BULGULAR ve TARTIŞMA}

\section{Tepe Püskülü Çıkış Süresi}

Mısır bitkisinin yetiştirilmesine esas $\geq 10{ }^{\circ} \mathrm{C}$ sıcaklığın gün sayısı bakımından Muş ili yaklaşık 181 güne sahip [16] olmakla birlikte sicaklık uygun olmasına rağmen Mayıs ayının yağışlı geçmesi sebebiyle ekim gecikebilmektedir. $\mathrm{Bu}$ açıdan erkencilikte önemli bir kriter olan çiçeklenme süresi bakımından, genotipler arasında önemli farklılıklar tespit edilmiştir. FAO olum grubu 450 olan Ada-8924 genotipi 59.0 gün ile en erkenci olarak belirlenirken, Suerto, Kalends ve Dekalp 6724 çeşitleri ise 72.0 gün ile en geç çiçeklenen çeşitler olmuşlardır (Tablo 3). Benzer çalışmalarda tepe püskülü çıkış süresini Acar ve ark. (2017) [17] 64-66 gün, Tezel ve ark.(2012) [8] 70-77 gün, Demiray ve Kılıç (2015) [6] 61.5-67.8, Özata ve ark. (2013) [18] 61.5-68 gün arasında tespit ettiklerini rapor etmektedirler. Çalışmalar arasında görülen farklılıklar çevre $\mathrm{x}$ genotip interaksiyonundan kaynaklandığ 1 düşünülmektedir.

\section{Bitki Boyu}

Bitki boyu bakımında genotipler arasında önemli bir farklılık tespit edilememiştir. Bitki boyu ile alakalı benzer çalışmalarda Soylu ve ark. (2008) [19]; Demiray ve Kılıç (2015) [6] önemli bir farklılık tespit edemezken, diğer bazı çalışmalarda önemli farklılıklar tespit edilmiştir $[18,8,17]$. Verime doğrudan etkisinin \%27$\% 35$ dir [20]. Bitki boyunda farkın görülmemesi, birbirine yakın verim potansiyeline sahip çeşitlerin optimum toprak ve iklim şartlarında ortam bulmasıyla izah edilebilir. Nitekim Weaich ve ark. (1996) [21], Cairns ve ark., (2012) [22] gerek bitki boyu ve gerekse ilk koçan yüksekliğini belirleyen başlıca faktörün yüksek sıcaklık olduğunu bildirmektedirler.

\section{İlk Koçan Yüksekliği}

Makineli hasatta $1 \mathrm{~m}$ altında olması arzu edilmeyen ilk koçan yüksekliği bakımından bitki boyunda olduğu gibi çeşitler arasında önemli bir farklılık tespit edilememiştir. Çeşitler çoğunlukla 1 m'nin üstünde değer kaydetmişlerdir. Tezel ve ark. (2012) [8], Kılınç ve ark. (2018) [23] ilk koçan yüksekliği bakımından ele aldıkları çeşitler arasında fark bulmazken, çeşitler arasında farkın olduğunu rapor eden araştırıcılardan Özata ve ark. (2013) [18] 109.2-145 cm $\mathrm{cm}^{-1}$; Demiray ve Kılıç (2015) [6] 88.4$107.4 \mathrm{~cm}^{-1}$; Acar ve ark. (2017) [17] 94-114 $\mathrm{cm}^{-1}$ arasında farklı değerler elde ettiklerini bildirmişlerdir.

Tablo 3. Çiçeklenme Gün Sayısı, Bitki Boyu, İlk Koçan Yüksekliğine Ait Ortalama Değerler ve Tukey (\%5) Testine Göre Oluşan Gruplar

\begin{tabular}{|c|c|c|c|}
\hline Çeşitler & $\begin{array}{l}\text { Tepe püskülü } \\
\text { ç1k1ş süresi } \\
\left(\text { gün }^{-1}\right)\end{array}$ & $\begin{array}{l}\text { Bitki boyu } \\
\left(\mathrm{cm}^{-1}\right)\end{array}$ & $\begin{array}{l}\text { İlk koçan } \\
\text { yüksekliği }\left(\mathrm{cm}^{-1}\right)\end{array}$ \\
\hline Sakarya & $69,00 \mathrm{c}$ & 300,60 & 119,75 \\
\hline Agn 720 & $70,50 \mathrm{~b}$ & 310,90 & 118,85 \\
\hline Dekalp 6101 & $66,00 \mathrm{e}$ & 303,25 & 97,65 \\
\hline Suerto & $72,00 \mathrm{a}$ & 303,70 & 109,85 \\
\hline Ada 8924 & $59,00 \mathrm{f}$ & 296,95 & 98,65 \\
\hline Ada 523 & $70,50 \mathrm{~b}$ & 326,60 & 122,70 \\
\hline Adasa 16 & $71,75 a b$ & 302,20 & 113,75 \\
\hline Kalends & $72,00 \mathrm{a}$ & 294,60 & 127,25 \\
\hline Ada 334 & $68,50 \mathrm{~cd}$ & 323,70 & 132,00 \\
\hline Dekalp 6724 & $72,00 \mathrm{a}$ & 292,70 & 98,90 \\
\hline Kws Kebos & $72,25 \mathrm{a}$ & 284,65 & 102,10 \\
\hline As 71 & $68,25 \mathrm{~cd}$ & 299,35 & 98,40 \\
\hline Fito Carella & $72,25 \mathrm{a}$ & 308,20 & 111,75 \\
\hline Breaker & $67,50 \mathrm{~d}$ & 335,60 & 128,35 \\
\hline Dekalp 5783 & $64,75 \mathrm{e}$ & 282,15 & 108,15 \\
\hline F & $182.6 * *$ & 1.71 ÖD & 1.74 ÖD \\
\hline
\end{tabular}

\section{Dane/Koçan Oranı}

Dane verimi ile olumlu bir ilişkiye sahip dane/koçan oranı bakımından ortalamalar incelendiğinde çeşitler istatistikî açıdan $\mathrm{P}<0.01$ seviyesinde önemli olduğu Tablo 4'ten anlaşılmaktadır. Çeşitler \%74.3-85.8 arasında değişim göstermiş olup, söz konusu farklılık genotipik farklılıkla açıklanabilmektedir. Çalışmamızla benzer sonuçlar elde eden Saygı ve Toklu (2017) [24] \%97.7-123.9; Tezel ve ark. (2012) [8] ise \%78.5-87.5 ise arasında değerler elde ettiklerini bildirmişlerdir.

\section{Koçanda Dane Sayısı}

Koçanda dane sayısı bakımından çeşitler arasında $\mathrm{P}<0.01$ seviyesinde önemli farklılıkların olduğu görülmektedir 
(Tablo 4). Dane de koçan sayıları 497.8- 736.8 arasında değişmiştir. Türkay ve ark. (2002) [25], İdikut ve Kara (2013) [26], Sayg1 ve Toklu (2017) [24] koçanda tane sayısı açısından çeşitler arasında farklılık olduğunu belirttikleri bulguları, sonuçlarımızı desteklemektedir.

\section{Koçanda Dane Ağırlığı}

Koçanda dane ağırlığı açısından çeşitler arasında $\mathrm{P}<0.01$ seviyesinde önemli farklılıkların olduğu Tablo 4'ten anlaşılmaktadır. Değerler 76.6-135.8 $\mathrm{g} \mathrm{koçan}^{-1}$ arasında değişmiş olup, sonuçlarımız koçanda dane ağırlı̆̆ bakımından farklılık bulduklarını bildiren İdikut ve Kara (2013) [26], Demiray ve Kılıç (2015) [6], Sayg1 ve Toklu (2017) [24] gibi araştırıcıların bulguları ile uyumludur.

\section{Bitkide Koçan Sayısı}

Bitkide koçan sayısı bakımından varyans analiz sonuçları incelendiğinde çeşitler arasındaki farkın önemli olmadığ 1 belirlenmiştir. Buna göre denemede en yüksek bitkide koçan sayısı 1,28 adet/bitki ile Dekalp 6101 çeşidinden elde edilirken en düşük bitkide koçan sayısı ise 1,03 adet/bitki ile Fito Carella çeşidinden elde edildiği belirlenmiştir. Mısır çeşitlerinin bitkide koçan sayısına ilişkin benzer çalışmalarda; Serin ve Bulut (2013) [27] önemli farklılıklar bildirirken, Sayaslan ve ark. (2010) [28] da ele alınan çeşitler arasında önemli farklar bulmadıklarını bildirmişılerdir.

Tablo 4. Bitkide Koçan Sayısı, Dane Koçan Oranı ve Koçanda Dane Sayısısına Ait Ortalama Değerler ile Tukey (\%5) testine göre oluşan gruplar

\begin{tabular}{llll}
\hline Çeşitler & $\begin{array}{l}\text { Bitkide } \\
\text { koçan sayıs1 } \\
\text { ad bitki }\end{array}$ & $\begin{array}{l}\text { Dane/koçan } \\
\text { oranı } \%\end{array}$ & $\begin{array}{l}\text { Koçanda } \\
\text { dane sayıs1 } \\
\text { ad koçan }\end{array}$ \\
Sakarya & 1,19 & $75,9 \mathrm{de}$ & $708,2 \mathrm{ab}$ \\
Agn 720 & 1,17 & $78,1 \mathrm{~cd}$ & $736,8 \mathrm{a}$ \\
Dekalp 6101 & 1,28 & $83,1 \mathrm{ab}$ & $547,3 \mathrm{abc}$ \\
Suerto & 1,13 & $79,4 \mathrm{~cd}$ & $604,3 \mathrm{abc}$ \\
Ada 8924 & 1,08 & $77,8 \mathrm{cde}$ & $567,3 \mathrm{abc}$ \\
Ada 523 & 1,13 & $80,6 \mathrm{bc}$ & $511,3 \mathrm{c}$ \\
Adasa 16 & 1,07 & $79,0 \mathrm{~cd}$ & $543,0 \mathrm{abc}$ \\
Kalends & 1,06 & $80,7 \mathrm{bc}$ & $497,8 \mathrm{c}$ \\
Ada 334 & 1,14 & $79,3 \mathrm{~cd}$ & $613,8 \mathrm{abc}$ \\
Dekalp 6724 & 1,10 & $83,7 \mathrm{ab}$ & $594,5 \mathrm{abc}$ \\
Kws Kebos & 1,09 & $74,3 \mathrm{e}$ & $675,0 \mathrm{abc}$ \\
As 71 & 1,09 & $78,9 \mathrm{~cd}$ & $529,3 \mathrm{bc}$ \\
Fito Carella & 1,03 & $77,6 \mathrm{cde}$ & $556,3 \mathrm{abc}$ \\
Breaker & 1,20 & $79,1 \mathrm{~cd}$ & $569,0 \mathrm{abc}$ \\
Dekalp 5783 & 1,05 & $85.8 \mathrm{a}$ & $615,0 \mathrm{abc}$ \\
F & 0.99 ÖD & $17.0 * *$ & $3.29 * *$
\end{tabular}

*: $\mathrm{p} \leq 0,05$ düzeyinde, ${ }^{* *}: \mathrm{p} \leq 0,01$ düzeyinde önemli

\section{Bin Dane A ğırlığı}

Bin dane ağırlığı bakımından çeşitler arasında $\mathrm{P}<0.01$ seviyesinde önemli farklılıkların tespit edilmiş olup, en yüksek bin dane ağırlığı $227.7 \mathrm{~g}^{-1}$ ile Dekalp-6101'den, $15.5 \mathrm{~g}^{-1}$ ile Adasa-16 çeşidinden elde edilmiştir (Tablo 5). Genotipik etki altında olmakla birlikte bin dane ağırlığında çevre şartları özellikle de sıcaklık önemli bir belirleyicidir. Zira $30{ }^{\circ} \mathrm{C}$ üzerindeki sıcaklıklar fotosentez verimini düşürmekte yanısıra dane doldurma süresini de kısaltmaktadır [29]. Çiçeklenmenin başladığ Ağustos ayı başları maksimum sıcaklık ortlaması sınır civarda seyretmiştir.

\section{Hasad Nemi}

Hasad nemi bakımından çeşitler arasında $\mathrm{P}<0.01$ seviyesinde önemli farklılıklar tespit edilmiştir (Tablo 5). En düşük hasad nemi \%30 ile dekalp-6101 çeşidinden elde edilirken, en yüksek hasad nemi de \%35.6 ile Dekalp 5783 ve Agn-720 çeşitlerinden elde edilmiştir. Bir bölgede misır yetişticiliğini belirleyen faktörlerin başında uygun hasad nemi gelmektedir. Sezonun kısalığ1 danelerin yeterince kuruyamaması sonucu makineli hasata zorluklar yaşanabilmektedir. Denemeye ait hasad neminin \%28 ve üzeri kaydedilmesi geniş alanlar düşünüldüğünde makineli hasad için önemli bir engel olarak görülmektedir. Tezel ve ark. (2012) [8] Konya şartlarında \%14.2-26, Özata ve ark. (2013) [18] Samsun şartlarında \%18.9-26.7, Vartanlı ve Emeklier (2007) [29] Ankara şartlarında \%21.5-28.6 olarak bulduklarını bildirmişlerdir. Çalışmamızda hasad neminin \%30 ve üzeri kaydedilmesi uygun sıcaklığa rağmen yağışlardan dolayı tarlanın ekime imkân tanımaması sonucu ekimin 1 Haziran tarihine sarkması sebep olarak gösterilebilir.

Tablo 5. Koçan Dane Ağırlığı, Din Dane Ağırlığı Ve Hasad Nemine Ait Ortalama Değerler İle Tukey (\%5) testine göre oluşan gruplar

\begin{tabular}{llll}
\hline Çeşitler & $\begin{array}{l}\text { Koçan dane } \\
\text { ağılı̆ı̆ } \mathrm{g} \\
\text { koçann }^{-1}\end{array}$ & $\begin{array}{l}\text { Bin dane } \\
\text { ağırlığ }\left(\mathrm{g}^{-1)}\right.\end{array}$ & $\begin{array}{l}\text { Hasat } \\
\text { nemi }(\%)\end{array}$ \\
\hline Sakarya & $116,1 \mathrm{abc}$ & $166,4 \mathrm{bc}$ & $33,9 \mathrm{abc}$ \\
Agn 720 & $120,5 \mathrm{abc}$ & $197,1 \mathrm{ab}$ & $35,6 \mathrm{ab}$ \\
Dekalp 6101 & $134,5 \mathrm{ab}$ & $227,7 \mathrm{a}$ & $30,0 \mathrm{c}$ \\
Suerto & $105,3 \mathrm{abc}$ & $166,1 \mathrm{bc}$ & $33,2 \mathrm{abc}$ \\
Ada 8924 & $102,3 \mathrm{abc}$ & $178,8 \mathrm{abc}$ & $30,7 \mathrm{bc}$ \\
Ada 523 & $104,93 \mathrm{abc}$ & $199,6 \mathrm{ab}$ & $35,3 \mathrm{ab}$ \\
Adasa 16 & $76,6 \mathrm{c}$ & $145,5 \mathrm{c}$ & $34,8 \mathrm{abc}$ \\
Kalends & $113,3 \mathrm{abc}$ & $201,4 \mathrm{ab}$ & $34,8 \mathrm{abc}$ \\
Ada 334 & $87,0 \mathrm{c}$ & $162,5 \mathrm{bc}$ & $35,4 \mathrm{ab}$ \\
Dekalp 6724 & $135,8 \mathrm{a}$ & $198,8 \mathrm{ab}$ & $34,3 \mathrm{abc}$ \\
Kws Kebos & $120,0 \mathrm{abc}$ & $196,6 \mathrm{ab}$ & $33,0 \mathrm{abc}$ \\
As 71 & $117,8 \mathrm{abc}$ & $196,6 \mathrm{ab}$ & $32,6 \mathrm{abc}$ \\
Fito Carella & $105,9 \mathrm{abc}$ & $193,7 \mathrm{abc}$ & $32,4 \mathrm{abc}$ \\
Breaker & $89,9 \mathrm{bc}$ & $186,7 \mathrm{abc}$ & $33,8 \mathrm{abc} *$ \\
Dekalp 5783 & $112,2 \mathrm{abc}$ & $191,8 \mathrm{abc}$ & $35,6 \mathrm{ab}$ \\
F & $3.45 * *$ & $4.57 * *$ & $3,59 * *$ \\
\hline *: p $\leq 0,05$ düzeyinde, $* * \mathrm{p} \leq 0,01$ düzeyinde önemli &
\end{tabular}

\section{Ham Protein Oranı}

Yem değeri açısından önem verilen bir özellik olan danede ham protein oranı bakımından çeşitler arasında $\mathrm{P}<0.01$ seviyesinde önemli farkl1lıkllar tespit edilmiştir (Tablo 5). Dekalp-5783 ve Suerto \%10 ile en yüksek ham protein oranına sahip olurken, Kalends ise \%5.8 ile en düşük orana sahip olmuştur. Ana ürün dane misır ile alakalı çalışmalarda Vartanlı (2005) [30], \%6.2-8.7; Kahraman (2016) [31] \%7.9-8.6; Kılınç ve ark. (2018) [23] \%7.8-9.0 arasında ham protein oranı tespit ettiklerini belirtmişlerdir. 


\section{Dane Verimi}

Dane verimi bakımında çeşitler arasında $\mathrm{P}<0.05$ seviyesinde önemli farklılılar tespit edilmiştir (Tablo 6). Çalışmada Dekalp-6724 (1193.9 kg da $\left.{ }^{-1}\right)$, Kalends (1167.4 $\left.\mathrm{kg} \mathrm{da}^{-1}\right)$ ile As-71 (1141.9 $\left.\mathrm{kg} \mathrm{da}^{-1}\right)$ ilk üç sırayı paylaşırken, Adasa-16 $800.7 \mathrm{~kg} \mathrm{da}^{-1}$ ile en düşük dane verimine sahip olmuştur. Dane veriminin çeşit ve genotiplere gore farklılık arz ettiği muhtelif çalışmalarla da belirlenmiştir [32, 18, 33, 12, 16].

Tablo 6. Protein Oranı ve Dane Verimine Ait Ortalama Değerler İle Tukey (\%5) testine göre oluşan gruplar

\begin{tabular}{llll}
\hline Çeşitler & $\begin{array}{l}\text { Protein oran1 } \\
(\%)\end{array}$ & $\begin{array}{l}\text { Dane verimi } \\
\mathrm{da}^{-1}\end{array}$ \\
\hline Sakarya & $6,4 \mathrm{~cd}$ & $929,1 \mathrm{ab}$ \\
Agn 720 & $6,4 \mathrm{~cd}$ & $1068,0 \mathrm{ab}$ \\
Dekalp 6101 & $\begin{array}{l}\text { 6,8 bcd } \\
1058,2 \mathrm{ab}\end{array}$ \\
Suerto & $10,0 \mathrm{a}$ & $1052,3 \mathrm{ab}$ \\
Ada 8924 & $8,2 \mathrm{abc}$ & $925,1 \mathrm{ab}$ \\
Ada 523 & $8,7 \mathrm{ab}$ & $947,6 \mathrm{ab}$ \\
Adasa 16 & $6,6 \mathrm{~cd}$ & $800,7 \mathrm{~b}$ \\
Kalends & $5,8 \mathrm{~d}$ & $1167,4 \mathrm{ab}$ \\
Ada 334 & $7,2 \mathrm{bcd}$ & $925,1 \mathrm{ab}$ \\
Dekalp 6724 & $6,8 \mathrm{bcd}$ & $1193,9 \mathrm{a}$ \\
Kws Kebos & $7,0 \mathrm{bcd}$ & $1105,5 \mathrm{ab}$ \\
As 71 & $6,4 \mathrm{~cd} *$ & $1141,9 \mathrm{ab}$ \\
Fito Carella & $6,4 \mathrm{~cd}$ & $1096,9 \mathrm{ab}$ \\
Breaker & $6,8 \mathrm{bcd}$ & $986,5 \mathrm{ab}$ \\
Dekalp 5783 & $10,0 \mathrm{a}$ & $1104,4 \mathrm{ab}$ \\
F & $8.77 * *$ & $2.21 *$ \\
\hline
\end{tabular}

*: $\mathrm{p} \leq 0,05$ düzeyinde, $* *: \mathrm{p} \leq 0,01$ düzeyinde önemli

\section{SONUÇ ve ÖNERILER}

Denemeden elde edilen sonuçlara göre; Muş ilinde $\geq 10$ ${ }^{\circ} \mathrm{C}$ sicaklığa sahip 180 günlük bir yetiştirme peryodunun varlığı ana ürün dane amaçlı misır yetiştirilmesini mümkün kılmaktadır. Denemeye alınan çeşitler birbirine yakın değerlere sahip olamkala birlikte daha yüksek dane verimleriyle öne çıkan Dekalp 6724, Kalends ve As71'ın Muş ekolojik şartları için ümitvar oldukları tespit edilmiştir. Yazlık yetişme sezonunun sınırlı olduğu bu tür bölgelerde ekim zamanı önemli bir belirleyicidir. $\mathrm{Bu}$ bakımdan mısır ekim işleminin Mayıs ayının ilk haftasindan itibaren tarlaya girme firsatları değerlendirilmek suretiyle yapılması, yüksek verim ve daha düşük hasat nemini yakalama açısından önem arz etmektedir.

\section{KAYNAKÇA}

[1] TMO. Toprak Mahsulleri Ofisi Genel Müdürlüğü 2019 Y11 Hububat Sektör https://www.tmo.gov.tr/Upload/Document/sektorraporlari /hububat2019.pdf. (23.02.2021).

[2] Avc1 M., Kaplan O., Denek N. Değişik Katkılarla Hazırlanan Misır Sapı Haylaj Kalitesinin Belirlenmesi Harran Üniv Vet Fak Derg., 2:1 32-35, 2013.
[3] TÜİK. Tarım İstatistikleri, Türkiye İstatistik Kurumu, http://www.tuik.gov.tr/UstMenu.do?metod=temelist), 2020.

[4] Anonim. Muş Tarım Orman İl müdürlüğü İstatistik kayitları, 2020.

[5] Ayrancı R., Sade B. Konya ekolojik şartlarında yetiştirilebilecek atdişi melez misır (Zea mays L. indentata Sturt.) çeşitlerinin belirlenmesi. Bitkisel Araştırma Dergisi, 2:1 6-14, 2004.

[6] Demiray Y.G., Kılıç H. Bingöl Ekolojik Şartlarına Uygun Tane Mısır (Zea mays L.) Çeşitlerinin Belirlenmesi” 11. Tarla Bitkileri Kongresi, Çanakkale s. 244, 2015.

[7] Tosun, F. Erzurum Ovasında Ekşi Silo ve Kesif Tane Yemi Olarak Melez Tarla Mısırı Yetiştirme İmkânları Üzerine Bir Araştırma. Atatürk Üniversitesi Ziraat Fakültesi Zirai Araştırma Enstitüsü Bülteni No: 21, A.Ü. Basımevi, s. 411967.

[8] Tezel M., Özcan G., Aksoyak Ş., Işık Ş. Konya Şartlarına Uygun Misır Çeşitlerinin Belirlenmesi Üzerine Bir Araştırma Tarım Bilimleri Araştırma Dergisi, 5:1 47-50, 2012.

[9] Kapar H., Öz A. Bazı Mısır Çeşitlerinin Orta Karadeniz Bölgesi'nde Performanslarının Belirlenmesi, Ondokuzmayıs Üniversitesi Ziraat Fakültesi Dergisi, 21:2 147-153, 2006.

[10] Kılıç H., Gül İ., Baytekin H. Diyarbakır sulu koşullarında bazı ön bitkilerin ikinci ürün mısırda verim ve bazı tarımsal karakterlere etkisi Türkiye 3.Tarla Bitkileri Kongresi Adana, 1 423-428, 1999.

[11] Anonim. Tarımsal değerleri ölçme denemeleri teknik talimatı (Mısır, Zeya mays L). T.C. Tarım Ve Orman Bakanlığı Bitkisel Üretim Genel Müdürlüğü Tohumluk Tescil ve Sertifikasyon Merkez Müdürlüğü, Ankara, 2018.

[12] Gül İ., Akıncı C., Doran İ., Kılıc H., Baytekın H. Effects of Different Previous Crops and Nitrogen Rates on Double Cropping Maize (Zea mays L.), Asian Journal of Chemistry, 20:4 2947-2954, 2008

[13] Sakin M.A., Bozdağ M., Çakar Ş. Tokat Kazova ve Zile Ana Ürün Koşullarında Yetiştirilen Melez Atdişi Mısır (Zea mays indentata L.) Çeşitlerinin Verim ve Verim Özelliklerinin Belirlenmesi Tarla Bitkileri Merkez Araştırma Enstitüsü Dergisi, 25:1 87-93, 2016.

[14] Olgun M., Başçiftçi, Z.B., Ayter, N.G., Kutlu, İ., Akın, A. Karaduman, Y. Ekmeklik Buğday (Triticum aestivum L.) Çeşitlerinde Protein Oranının Üç Farklı Analiz Yöntemine Göre Karşılaştırılması Üzerine Bir Araştırma, Süleyman Demirel Üniversitesi Ziraat Fakültesi Dergisi, 8:2 80-87, 2013.

[15] Caporaso N., Whitworth, M.B., Fisk, I.D. Protein content prediction in single wheat kernels using hyperspectral imaging. Food Chemistry, 240 32-42, 2018.

[16] Kırtok Y. Mısır üretimi ve Kullanımı. Nişasta ve Glikoz Üreticileri Derneği. Kocaoluk basım ve yayınevi. Tarsus. s.445, 1998.

[17] Acar N., Yılmaz M.F., Kara R. Kahramanmaraş Koşullarına Uygun Tane Mısır (Zea mays L.) Çeşitlerinin 
Belirlenmesi Tarla Bitkileri Merkez Araştırma Enstitüsü Dergisi, 26 80-85, 2017.

[18] Özata E., Geçit H.H., Öz A., Ünver S. Atdişi Hibrit Mısır Adaylarının Ana Ürün Koşullarında Performanslarının Belirlenmesi Determination of performance of some candidate dent corn under main crop conditions. Iğdır Univ. J. Inst. Sci. Tech., 3:1 91-98, 2013.

[19] Soylu S., Akman H., Gürbüz B. Konya Sarayönü Koşullarında Tane Mısır Yetiştiriciliği Üzerine Bir Araştırma. Ülkesel Tahıl Sempozyumu, 2-5 Haziran, Konya, s. 776-781, 2008.

[20] Sade B., Soylu S., Palta, Ç. Melez Mısır Çeşitlerinde Tane Verimi ve Verim Unsurları Arasındaki İlişkilerin Korelasyon, Path ve Faktör Analiz Yöntemleri İle Değerlendirmesi. Türkiye VI. Tarla Bitkileri Kongresi, 59 Eylül, Antalya, s. 989-994, 2005.

[21] Weaich K., Bristow K.L., Cass, A. Modeling preemergent maize shoot growth: II. High temperature stress conditions, Agronomy Journal, 88:3 98-403, 1996.

[22] Cairns J.E., Sonder K., Zaidi P.H., Verhulst N., Mahuku G., Babu R., Rashid, Z. Maize Production in a Changing Climate: Impacts, Adaptation, and Mitigation Strategies. Advances in agronomy, 114 1-58, 2012.

[23] Kılınç S., Karademir Ç., Ekin Z. Bazı Mısır (Zea mays L.) Çeşitlerinde Verim ve Kalite Özelliklerinin Belirlenmesi KSÜ Tarım ve Doğa Derg., 21:6 809-816, 2018.

[24] Saygı M., Toklu F. Çukurova Bölgesinde Birinci Ürün Koşullarında Yetiştirilen Bazı Danelik Mısır (Zea mays indentata Sturt.) Çeşitlerinin Dane Verimi, Bazı Bitkisel Özellikler ve Karakterler Arası İlişkiler Yönünden Değerlendirilmesi. KSÜ Doğa Bil. Derg., 20 308-312, 2017.

[25] Türkay M.A., Cerit İ., Sarıhan İ.H., Şen H.M., Çınar S., Ülger A.C. Farklı Azot Dozlarının At Dişi Melez Mısır Çeşitlerinde Tane Verimi ve Bazı Tarımsal Özelliklere Etkisi Üzerine Bir Araştırma. Çukurova Tarımsal Araştırma Enstitüsü, Tarla Bitki Araştırmaları ATK, Adana, 2002.

[26] İdikut L., Kara S.N. Tane Ürünü İçin Yetiştirilen İkinci Ürün Mısır Çeşitlerinin Bazı Verim Öğeleri İle Tane Nişasta Oranlarının Belirlenmesi KSÜ Doğa Bil. Derg., 16:1 8-15, 2013.

[27] Serin Y., Bulut S. Bazı mısır çeşitlerinin kayseri koşullarına adaptasyonu. Erciyes Üniversitesi Bilimsel Araştırma Projeleri Koordinasyon Birimi Proje No: FBA10-322, Kayseri, 2013.

[28] Sayaslan A., Gökmen S., Ülger A.C., Sakin M.A., Öz A., Duman A. Farklı bölgelerde ana ürün koşullarında yetiştirilen melez atdişi Misır (Zea mays indentata L.) çeşitlerinin verim ve yaş ögütme kalitesinin belirlenmesi. TOVAG-1070800 Nolu proje sonuç raporu, s. 76, 2010.

[29] Vartanlı S., Emeklier H.Y. Ankara Koşullarında Hibrit Mısır Çeşitlerinin Verim ve Kalite Özelliklerinin Belirlenmesi, Tarım Bilimleri Dergisi, 13:3 195-202, 2007.
[30] Vartanlı S. Ankara Koşullarında Hibrit Mısır Çesitlerinin Verim ve Kalite Özelliklerinin Belirlenmesi. Ankara Üniv. Fen Bilimleri Enstitüsü, Tarla Bitkileri ABD, Yüksek Lisans Tezi, s. 80, 2005.

[31] Kahraman Ş. Diyarbakır Koşullarında Ana Ve İkinci Ürün Tane Mısır Tarımında Bazı Tarımsal ve Teknolojik Özellikler Üzerine Araştırmalar. Dicle Üniversitesi Bilimleri Enstitüsü, Tarla Bitkileri ABD, Doktora Tezi, s. 167, 2016.

[32] Carvalho, H.W.L., Leal M.D.D., Santos M.X., Monteiro A.A.T., Cardoso M..J., Carvalho B.C.L. Stability of corncultivarsin three ecosystems of Brazilian Northeast. Pesquisa Agropecuaria Brasileira, 35:9 1773-1781, 2000.

[33] Kuşvuran A., Nazlı R.İ. Orta Kızılırmak Havzası ekolojik koşullarında bazı mısır (Zea mays L.) ceşitlerinin tane misır ozelliklerinin belirlenmesi. Yuzuncu Y1l Universitesi Tarım Bilimleri Dergisi, 24:3 233-240, 2014. 